\title{
Public Health and Community Medicine
}

RESEARCH ARTICLE

\section{Demographic Study on Hepatitis A Infections among Outpatients of Selected Hospitals within Kaduna Metropolis, Nigeria}

\author{
Timothy Waje ${ }^{1 *}$, Anthony John Dadah ${ }^{1}$, Muhammad Yusha' ${ }^{2}$ and Chanu lliyasu ${ }^{1}$ \\ ${ }^{1}$ Department of Microbiology, Faculty of Science, Kaduna State University, Kaduna, Nigeria \\ ${ }^{2}$ Department of Microbiology, Faculty of Science, Bayero University, Kano, Nigeria
}

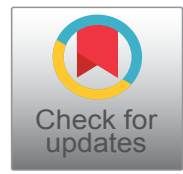

*Corresponding author: Timothy Waje, Department of Microbiology, Faculty of Science, Kaduna State University, P.M.B. 2339, Kaduna, Nigeria, Tel: +234-808-652-7453, E-mail: wajetim@yahoo.com

\begin{abstract}
Background: Hepatitis A infection formerly called infectious hepatitis is caused by the Hepatitis A Virus. The infection is transmitted primarily via the fecal-oral route through contaminated foods or drinks. The Virus poses a significant threat to public health because of its ability to cause fulminant hepatitis which still remains a point of concern.

Methods: A total of 300 samples were collected from six different hospitals within the metropolis. Fifty samples were collected from each of the hospital visited based on ethical approval from the State Ministry of Health. Blood group and Rhesus factor were tested from each sample using Blood Group antisera. The serum of each blood sample was tested for the presence of anti-HAV IgM using commercially available Micro-Point Rapid Test Kits.

Results: Results analysis revealed a prevalence rate of $0.67 \%$ for HAV among the studied population. This was regarded hypoendemic.

Conclusion: This study confirms previous reports about the downward trend in the global seroprevalence of HAV infections in many regions of the world. Young ages within 1120 years $(P \leq 0.04)$ and Blood transfusion $(P \leq 0.04)$ were identified as potential risk factors for HAV contraction within the metropolis.
\end{abstract}

\section{Keywords}

Demographic, Hepatitis A, Outpatients, Infection, Kaduna metropolis

\section{Introduction}

Hepatitis A formerly known as "Infectious Hepatitis, Epidemic hepatitis, Epidemic jaundice, Catarrhal jaundice and Type A Hepatitis- HA" is an infectious viral dis- ease of the liver caused by the Hepatitis A Virus [1,2]. The Virus is endemic in many developing countries of the world including Nigeria [2]. The Hepatitis A Virus has been associated with the etiology of fecally transmitted hepatitis worldwide [3]. The transmission of the virus is primarily through fecally contaminated foods and drinks and has also been associated with outbreaks among injection drug users, men who have sex with men and food handlers [4-7]. Though the virus causes a milder form of hepatitis which is self-limiting with a lifelong immunity and absence of chronic form, the dangers of debilitating symptoms and fulminant hepatitis (acute liver failure) by the virus still remains a point of concern $[5,8]$. Unlike Hepatitis B and C infections with asymptomatic cases, HAV infected persons often show symptoms of the virus [9]. Common symptoms associated with Hepatitis $\mathrm{A}$ infections include: Anorexia, nausea, vomiting, jaundice, dark urine, pale feces and elevated liver transaminase levels among others [5-11] The Hepatitis A Virus which is a member of the genus Hepatovirus of the Picornaviridae family has a small, naked icosahedral capsid and a single stranded (+ Strand) RNA consisting of approximately 7470 nucleotides [10-13]. The Virus is very resistant to chemical and physical agents and several minutes of boiling may be necessary to inactivate it [4]. When HAV is ingested, it enters the blood stream through the epithelial lining of the intestine then to the liver where replication occurs $[12,13]$. The Virus can also replicate in the gastrointestinal tract and spread to the liver via blood circulation [10]. Similar to the replication process of other viruses, uncoating occurs after viral 
attachment to liver cells and other few cell types, nucleic acid is freed thereby allowing replication to occur $[4,10]$. The virions are then localized in hepatocytes and kupffer cells, released into the bile, then into the stool where they are passed out with feces [12]. Unlike other picornaviruses, progeny virions of Hepatitis A Viral replication are released by exocytosis due to the non-cytolytic nature of the virus and no chronic form of the disease $[12,13]$. The specific routine diagnosis of acute hepatitis $A$ is made by finding anti-HAV IgM in the serum of the patients while an option is the detection of the Virus and/or antigen in the feces $[4,13,14]$. The Virus can be prevented and controlled by treatment of infected cases, improved sanitation and vaccination $[10,13]$. High prevalence of anti-Hepatitis A Virus immunoglobulin G antibody reported among healthcare facility attendees in Oshogbo, Nigeria [15]. Hepatitis A seroprevalence rates have decreased in many world regions during the past two decades [16]. As incidence rates decrease, the population shifts towards intermediate endemicity, the average age for infection increases and a growing proportion of children remain susceptible to HAV infection [8]. The most common risk factors for hepatitis $A$ infection include: Limited access to safe drinking water and other indicators of low socioeconomic status [17]. Other risk factors for HAV infections are related to resistance of HAV to the environment, poor sanitation in large areas of the world and abundant HAV shedding in feces [5]. This research sought to analyze some demographic features associated with HAV infections among the outpatient population of selected hospitals within the metropolis using Chi Square Test. Also, protection models and recommendations for mitigating the spread and severity of the virus among the human population to improve public health formed an important objective of this study.

\section{Significance of this Research to Public Health}

This work sought to assess the HAV disease burden among the general public within the Kaduna metropolis with a view to making recommendations that could check and mitigate risks of infection spread thereby improving public health within the Metropolis.

\section{Materials and Methods}

The study was conducted in six hospitals in June 2016. Three hospitals were public and three private selected at random within the Kaduna metropolis. Ethical clearance was obtained from the State Ministry of Health for samples collection from outpatients of these hospitals. Participants who were from age one to the elderly at ninety years were well informed about the study and its relevance to public health. Their consents to participate were sought through the use of consent forms. Parents and Guardians decided for patients less than 18 years. Structured questionnaires were issued to consented outpatients to provide demographic information for impact assessment through Chi Square analysis. The Inclusion criteria were ages 01 to 90 years as well as patient's positive response on the consent forms expressing their willingness to participate in the research. The exclusion criteria were ages less than one year and greater than 90 -years-old. Patients with negative or no response on the consent forms were also excluded from participation.

A total of 300 samples were collected based on a previous related prevalence rate of $18 \%$ for HBV obtained from the formula for sample size estimation in prevalence studies given by:

$$
\mathrm{N}=\frac{(Z)^{2} P(1-P)}{D^{2}}
$$

Where

$\mathrm{N}=$ Sample Size,

$Z=$ Statistics for 95\% Confidence Limit (1.96),

$\mathrm{P}=$ Prevalence rate of previous studies or related,

$D=$ Allowable error in research $(5 \%)[18,19]$.

Three milliliters $(\mathrm{ml})$ of blood was collected intravenously from each volunteered outpatient from the different hospitals using a $5 \mathrm{ml}$ syringe. This was immediately transferred into a plain blood sample bottle with the relevant label. The samples were taken to the Medical Microbiology Laboratory of Kaduna State University; Kaduna, Nigeria for Analysis. The ABO Blood group

Table 1: Age Group Distribution of Hepatitis A Infections Among Outpatients of Selected Hospitals Within Kaduna Metropolis

\begin{tabular}{|c|c|c|c|c|}
\hline Demographic Factor & $\begin{array}{l}\text { Number of Persons } \\
\text { Tested }\end{array}$ & $\begin{array}{l}\text { Number of Persons Reactive } \\
\text { to Anti HAV IgM }\end{array}$ & $\begin{array}{l}\text { Percentage of Reactive } \\
\text { Cases (\%) }\end{array}$ & $\begin{array}{l}\text { Probability }(P) \\
\text { Value } P \leq 0.05\end{array}$ \\
\hline \multicolumn{5}{|l|}{ Age-Group (Years) } \\
\hline $01-10$ & 31 & 1 & 3.22 & $P \leq 0.08$ \\
\hline $11-20$ & 26 & 1 & 3.82 & $P \leq 0.04$ \\
\hline $21-30$ & 76 & 0 & 0.00 & $P \leq 0.48$ \\
\hline $31-40$ & 90 & 0 & 0.00 & $P \leq 0.44$ \\
\hline $41-50$ & 49 & 0 & 0.00 & $P \leq 0.57$ \\
\hline $51-60$ & 16 & 0 & 0.00 & $P \leq 0.82$ \\
\hline $61-70$ & 8 & 0 & 0.00 & $P \leq 0.74$ \\
\hline $71-80$ & 3 & 0 & 0.00 & $P \leq 0.89$ \\
\hline $80-90$ & 1 & 0 & 0.00 & $P \leq 0.92$ \\
\hline Total & 300 & 2 & & \\
\hline
\end{tabular}


and Rhesus factor of each sample was determined using Blood group antisera. Serum was separated from each remaining blood sample by centrifuging at $1000 \mathrm{rpm}$ for 5 minutes. Micro-Point Rapid Diagnostic Test Kit (Made in USA) was used to test for the presence of anti-HAV IgM. All results were read and interpreted according to the manufacturer's instructions $[19,20]$. Results were tabulated according to demographic factors as shown in Table 1, Table 2, Table 3, Table 4, Table 5, Table 6 and Table 7. Chi Square test for associations between independent variables was used to determine the associations between the demographic factors and positivity for HAV antibody through test of significance at 5\% level of significance $[20,21]$.

\section{Results}

Out of the 300 samples from the 6 hospitals analyzed, 2 were positive for anti-HAV IgM. This accounted for $0.67 \%$ of the total samples tested. This was regarded hypoendemic based on the HAV severity rate classifica-

Table 2: Distribution of Hepatitis A Infection Among Outpatients of Selected Hospitals Within Kaduna Metropolis in Relation to Sex/Gender.

\begin{tabular}{|l|l|l|l|l|}
\hline Demographic Factor & $\begin{array}{l}\text { Number of } \\
\text { Persons Tested }\end{array}$ & $\begin{array}{l}\text { Number of Persons Reactive to } \\
\text { Anti HAV IgM }\end{array}$ & $\begin{array}{l}\text { Percentage of } \\
\text { Reactive Cases (\%) }\end{array}$ & $\begin{array}{l}\text { Probability (P) } \\
\text { Value P } \mathbf{0 . 0 5}\end{array}$ \\
\hline Gender/Sex & & & & \\
\hline Male & 114 & 1 & 0.88 & $P \leq 0.78$ \\
\hline Female & 186 & 1 & 0.54 & $P \leq 0.82$ \\
\hline Total & 300 & 2 & & \\
\hline
\end{tabular}

Table 3: Distribution of HAV Among Outpatients of Selected Hospitals Within Kaduna Metropolis in Relation to Blood Group.

\begin{tabular}{|l|l|l|l|l|}
\hline $\begin{array}{l}\text { Demographic } \\
\text { Factor }\end{array}$ & $\begin{array}{l}\text { Number of Persons } \\
\text { Tested }\end{array}$ & $\begin{array}{l}\text { Number of Persons Reactive to } \\
\text { Anti HAV IgM }\end{array}$ & $\begin{array}{l}\text { Percentage of Reactive Probability (P) Value } \\
\text { Cases (\%) }\end{array}$ & \begin{tabular}{l} 
P $\mathbf{0}$.05 \\
\hline Blood Group
\end{tabular} \\
\hline A & & & 0.00 & $P \leq 0.45$ \\
\hline B & 86 & 0 & 1.52 & $P \leq 0.40$ \\
\hline AB & 66 & 1 & 0.00 & $P \leq 0.76$ \\
\hline O & 13 & 0 & 0.74 & $P \leq 0.92$ \\
\hline Total & 135 & 1 & & \\
\hline
\end{tabular}

Table 4: Distribution of HAV Among Outpatients of Selected Hospitals Within Kaduna Metropolis in Relation to Rhesus Factor.

\begin{tabular}{|l|l|l|l|l|}
\hline Demographic Factor & $\begin{array}{l}\text { Number of Persons } \\
\text { Tested }\end{array}$ & $\begin{array}{l}\text { Number of Persons } \\
\text { Reactive to Anti HAV IgM }\end{array}$ & $\begin{array}{l}\text { Percentage of Reactive } \\
\text { Cases (\%) }\end{array}$ & P $\leq \mathbf{0 . 0 5}$ \\
\hline Rhesus Factor & & 2 & 0.70 & $P \leq 0.92$ \\
\hline $\mathrm{Rh}^{+}$ & 284 & 2 & 0.00 & $P \leq 0.74$ \\
\hline $\mathrm{Rh}^{-}$ & 16 & 0 & & \\
\hline Total & 300 & 2 & \\
\hline
\end{tabular}

Table 5: Distribution of HAV Infections Among Outpatients of Selected Hospitals Within Kaduna Metropolis in Relation to Social Factors.

\begin{tabular}{|l|l|l|l|l|}
\hline Demographic Factor & $\begin{array}{l}\text { Number of } \\
\text { Persons Tested }\end{array}$ & $\begin{array}{l}\text { Number of Persons Reactive } \\
\text { Anti HAV IgM }\end{array}$ & $\begin{array}{l}\text { Percentage of } \\
\text { Reactive Cases (\%) }\end{array}$ & $\begin{array}{l}\text { Probability (P) } \\
\text { Value P } \mathbf{0 . 0 5}\end{array}$ \\
\hline Social Factors & & & & \\
\hline Tribal Marks & 40 & 1 & 2.5 & $P \leq 0.16$ \\
\hline Have Knowledge of Hepatitis & 74 & 0 & 0.00 & $P \leq 0.48$ \\
\hline Eat in Public Places & 208 & 1 & 0.48 & $P \leq 0.74$ \\
\hline Sharing Clothes/Beddings & 212 & 2 & 0.94 & $P \leq 0.62$ \\
\hline HAV Positive Family History & 26 & 0 & 0.00 & $P \leq 0.68$ \\
\hline
\end{tabular}

Table 6: Distribution of Hepatitis A Infections Among Outpatients of Selected Hospitals Within Kaduna Metropolis in Relation to Individual Clinical History.

\begin{tabular}{|l|l|l|l|l|}
\hline Demographic Factor & $\begin{array}{l}\text { Number of } \\
\text { Persons Tested }\end{array}$ & $\begin{array}{l}\text { Number of Persons } \\
\text { Reactive to Anti HAV IgM }\end{array}$ & $\begin{array}{l}\text { Percentage of } \\
\text { Reactive Cases (\%) }\end{array}$ & $\begin{array}{l}\text { Probability (P) Value P } \\
\mathbf{0} \text {.05 }\end{array}$ \\
\hline Individual Clinical History & & & & $P \leq 0.04$ \\
\hline Blood Recipient & 24 & 1 & 4.17 & $P \leq 0.68$ \\
\hline Hypertension & 25 & 0 & 0.00 & $P \leq 0.76$ \\
\hline Diabetes & 13 & 0 & 0.00 & $P \leq 0.86$ \\
\hline HIVIAIDS & 5 & 0 & 0.00 & $P \leq 0.66$ \\
\hline Undiagnosed illnesses & 233 & 1 & 0.43 & \\
\hline Total & 300 & 2 & & \\
\hline
\end{tabular}


Table 7: Distribution of HAV Infections Among Outpatients of Selected Hospitals Within Kaduna Metropolis in Relation to Individual Level of Formal Education.

\begin{tabular}{|l|l|l|l|l|}
\hline Demographic Factor & $\begin{array}{l}\text { Number of Persons } \\
\text { Tested }\end{array}$ & $\begin{array}{l}\text { Number of Persons } \\
\text { Reactive to Anti HAV IgM }\end{array}$ & $\begin{array}{l}\text { Percentage of } \\
\text { Reactive Cases (\%) }\end{array}$ & $\begin{array}{l}\text { Probability (P) } \\
\text { Value P } \mathbf{0} \text { 0.05 }\end{array}$ \\
\hline Level of Formal Education & & & & \\
\hline No Formal Education & 28 & 0 & 0.00 & $P \leq 0.66$ \\
\hline Primary Education & 56 & 1 & 1.79 & $P \leq 0.30$ \\
\hline Secondary Education & 95 & 0 & 0.00 & $P \leq 0.43$ \\
\hline Tertiary Education & 121 & 1 & 0.83 & $P \leq 0.82$ \\
\hline Total & 300 & 2 & & \\
\hline
\end{tabular}

Table 8: Prevalence and Severity Rate for Hepatitis A Infections Among Outpatients Within Kaduna Metropolis, Nigeria.

\begin{tabular}{|l|l|l|l|}
\hline Anti HAV IgM reaction & Number of Persons & Percentages (\%) & HAV Endemicity Classification \\
\hline Positive & 2 & 0.67 & Hypo-endemic \\
\hline Negative & 298 & 99.33 & \\
\hline Total & 300 & 100 & \\
\hline
\end{tabular}

tion defined as: Low $=50 \%$ intermediate $=51-89 \%$, High $=\geq 90 \%$ [22]. The remaining 298 (99.33\%) samples were negative for the HAV antibody (Table 8).

Analysis of 31 samples within age group 01-10 years revealed 1 (3.22\%) positive case for HAV antibody. Similarly, 1 (3.82\%) positive case was observed among 26 outpatients within age group $11-20$ years. On the contrary, no positive case for anti-HAV IgM was observed among the remaining 243 samples within age group 21 90 years $(0,0.00 \%)$ (Table 1$)$. There was a statistically significant association between age group 11-20 years and anti-HAV IgM seropositivity $(P \leq 0.04)$ [23]. A mean age of 32.20 years (95\% Confidence Interval of $32.20 \pm$ 2.01 years) was obtained as a measure of central tendency among the subjects at risk of contraction of this virus (Appendix).

Among the 300 samples analyzed, 114 were from Males and 186 from females. One male sample $(0.88 \%)$ tested positive for anti-HAV IgM and 1 (0.54\%) from females was also positive for the HAV antibody. There were no statistically significant associations between male or female gender and anti-HAV IgM positivity $(P \leq$ $0.78, P \leq 0.82$ ) (Table 2).

Table 3 shows the distribution of HAV infections according to the blood group of the studied subjects. Out of 86 samples from blood group A outpatients, none $(0$, $0.00 \%)$ was reactive to anti-HAV IgM. One (1.52\%) out of 66 patients with blood group $B$ was positive for the HAV antibody. No positive case $(0,0.00 \%)$ was observed among 13 individuals with blood group $A B$ while 1 $(0.74 \%)$ positive case was obtained among 135 samples from blood group $\mathrm{O}$ individuals. There were no statistically significant associations between any blood group and positivity for anti-HAV IgM respectively $(P \leq 0.45, P$ $\leq 0.40, P \leq 0.76, P \leq 0.92)$.

Out of the 300 samples tested, 284 were Rhesus positive $\left(\mathrm{Rh}^{+}\right)$out of which $2(0.70 \%)$ tested positive for anti -HAV IgM. The remaining 16 samples were Rhesus negative $\left(\mathrm{Rh}^{-}\right)$with none $(0.00 \%)$ reactive to the HAV antibody. There were no statistically significant associations between Rhesus factor and positivity for anti-HAV IgM respectively ( $P \leq 0.92, P \leq 0.74)$ (Table 4$)$.

Table 5 shows the various social factors analyzed. One $(2.5 \%)$ out of the 40 samples with tribal marks tested positive for anti-HAV IgM. No positive case $(0.00 \%)$ was observed among the 74 subjects with knowledge of Hepatitis. On the other hand, one $(0.48 \%)$ person out of 208 outpatients that eat in public places tested positive for anti-HAV IgM while $2(0.94 \%)$ out of the 212 samples from outpatients that share clothes or beddings were reactive to the HAV antibody. There was no positive case among 26 outpatients from families with a positive history of HAV infections. Similarly, no significant association was observed between any social factor and anti-HAV IgM positivity.

Out of 24 blood recipients that participated, 1 (4.17\%) was positive for the HAV antibody. On the other hand, there were no positive cases among the 25 outpatients with history of Hypertension (0, $0.00 \%), 13$ persons with diabetes $(0,0.00 \%)$ and 5 HIV/AIDS patients $(0,0.00 \%)$ respectively. One $(0.43 \%)$ out of the 233 outpatients with undiagnosed illnesses was reactive to the anti-HAV IgM. There was a statistically significant association between blood recipient (transfusion) and positivity for anti-HAV IgM $(P \leq 0.04)$. On the contrary, no significant associations were observed between other Individual Clinical History and positivity for HAV antibody respectively (Table 6).

Analysis of the 28 samples from outpatients without formal education revealed no positive case for anti-HAV IgM. One (1.79\%) out of the 56 samples with primary school level of education was reactive to the HAV antibody. None $(0,0.00 \%)$ of the 95 samples from those that attended secondary school level of education was positive for anti-HAV IgM while $1(0.83 \%)$ out of the 121 samples from patients that attended tertiary education reacted to the HAV antibody. There were no statistically significance associations between the subject's levels of formal education and anti-HAV positivity respectively ( $P$ $\leq 0.66, P \leq 0.30, P \leq 0.43, P \leq 0.82$ ) (Table 7). 


\section{Discussion}

The Hepatitis A Virus has been listed along Hepatitis $B$ and Hepatitis $C$ Viruses as common causes of prevailing viral hepatitis in some locations of the world with new and emerging cases of different severity [24]. Nevertheless, the epidemiology of Hepatitis A has been experiencing a spirally downward trend in many locations of the globe in recent years $[16,25]$. This could probably be due to either effective used of available HAV vaccine or increasing awareness and compliance with personal hygiene around the nations of the world. The $0.67 \%$ prevalence rate obtained in this study is classified as hypoendemicity. The HAV endemicity rates were defined as: Low $=\leq 50 \%$ intermediate $=51-89 \%$, High $=\geq 90 \%$ [22]. This revealed a similar trend dropping from a previous report of $7.2 \%$ among young adolescent and school children in Kaduna in 2013 to the present rate [2,22]. This low prevalence rate could suggest effective used of available HAV vaccines among the inhabitants of the City. Improvements in urban facilities with increasing sanitation and personal hygiene might have also played a vital role in this reduction of HAV prevalence among the inhabitants of the metropolis. Also, the use of antiHAV-IgG immunoenzymatic assay in the previous study and anti IgM kits in this study might have contributed to the difference in the two results. The result of this study is also similar to the trend reported among food handlers in Khartoum locality, Sudan (4.40\%) and 37.25\% in central Karnataka, India with same category of endemicity but varying prevalence rates $[7,22,26]$. This similarity could be attributed to the general downward trend in the global seroprevalence of HAV infections in most countries of the world. On the other hand, location differences might have been responsible for the varying rates in the different reports hence prevalence rates have been reported to vary from country to country and even within the same country from one city to another $[16,25,26]$.

Age is an important decimal in the epidemiology and control of infectious diseases. It is central to the definition of a host's susceptibility to infection by a particular pathogen at a particular time. The $2(0.67 \%)$ positive cases for anti-HAV IgM obtained in this study were within age groups 01-10 years and 11-20 years suggesting these age groups were at risk of contraction of the Virus. This could probably be due to the several channels of exposure to the virus associated with persons within these ages. On the other hand, the absence of any positive case in older adults within age group 21-90 years suggested HAV to be common in younger ages than in older adults. This could probably be due to the exposure of younger subjects to unhygienic materials which serve as sources of infection as well as non-compliance to personal hygiene among these age groups. These agree with a previous report about HAV infections among schoolchildren and young adolescence (Ages 2-19) in Kaduna [2]. Though seropositivity for HAV antibody occurred within age groups $01-10$ and $11-20$ years respectively, the statistically significant association observed between age group 11-20 years and positivity for HAV antibody ( $P \leq$ 0.04 ) suggests persons within this age group are at risk of HAV contraction. This could probably be attributed to exposures to various sources of HAV infection including play grounds. The absence of a significant association between age group 01-10 years and HAV antibody positivity could be attributed to close parental monitoring for this age group which alleviates their exposures to sources of HAV infections $(P \leq 0.08)$. The absence of a statistically significant association between the respective age groups from 21-90 years and seropositivity for anti-HAV IgM suggest a decreasing trend in the contraction of HAV as age progresses. This could probably be due to improvements in personal hygiene and the ability to avoid contaminated foods and drinks thereby complying with personal hygiene by adults. On the contrary, previous studies in other countries of the world have reported high prevalence for anti-HAV antibody among children such as: $51.4 \%$ among schoolchildren in Catalonia Spain, 60\% prevalence among school children in central Tunisia and $61.4 \%$ among children in Egypt [2729]. These dissimilarities may not be unconnected from the fact that prevalence rates for HAV antibody varies from one country to another and even within the same country from city to city probably due to variations in socio-economic status [26].

The absence of statistically significant associations between gender (Male or Female) and anti-HAV IgM positivity suggests that gender is not a predisposition factor for HAV contraction $(P \leq 0.78, P \leq 0.82)$. Moreover, one positive case was from a male and the other from a female. This is similar to the trend reported for HAV total antibodies among children in Akpabuyo LGA of Cross River State, Nigeria but with differences in prevalence rates probably due to differing number of study subjects, location, traditions and lifestyles $[26,30]$.

Blood group is important in infectious disease epidemiology because of the role of blood group antigens in immunity. Some infectious diseases susceptibility has been associated with certain blood groups [31,32]. The absence of a statistically significant association between the respective blood groups and anti-HAV IgM positivity suggest equal predisposition of the outpatients to HAV infection regardless of their blood groups $(P \leq 0.45, P \leq$ $0.40, P \leq 0.76, P \leq 0.92)$. This could also mean that none of the blood group type among the studied subjects had advantage over the other by conferring immunity due to blood group antigens against the Hepatitis A Virus. Furthermore, this study revealed more individuals with Blood group $O(135 / 300)$ to be common than other Blood groups. This agrees with other reports in other locations such as: Among blood donors (231/300) in Portharcourt city, Nigeria and 119/347 blood donors in the Al-Ramadi city of Bagdad [33,34]. 
The larger number of Rhesus positive (284/300) than Rhesus negative (16/300) individuals encountered in this study showed that Rhesus positive persons were more common than Rhesus negative individuals within the metropolis. This confirmed previous reports in other locations of the world such as: 115/130 among blood donors in a Research Centre Istafan, Iran and 5984/6361 among blood donors in Gondar University Teaching Hospital Ethiopia $[35,36]$. No statistically significant associations were observed between Rhesus factors and HAV positivity respectively $(P \leq 0.74, P \leq 0.92)$. These suggest that Rhesus factor did not influence the subject's positivity for anti-HAV IgM.

The absence of statistically significant associations between the respective social factors analyzed and anti-HAV IgM positivity could suggest none of these factors posed a significant risk to HAV contraction among the studied subjects within the metropolis $(P \leq 0.16, P \leq$ $0.48, P \leq 0.74, P \leq 0.62, P \leq 0.68)$. More so, the absence of a statistically significant association between eating in public places and anti-HAV IgM positivity could suggest improvements on hygiene and environmental sanitation in public eateries within the metropolis.

One (4.17\%) subject positive for HAV antibody was a blood recipient. The probability value revealed a significant association between positivity for HAV antibody and blood transfusion $(P \leq 0.04)$. This suggests that transfusion of infected blood could pose a significant risk to HAV contraction among the inhabitants of the metropolis especially if it is not properly screened. This confirmed previous reports enlisting HAV as a transfusion transmissible pathogen [37]. It is worthy of note that HAV causes mild hepatitis but pose a significant risk for fulminant hepatitis which could be dangerous causing acute liver failure $[5,8]$. Other diseases analyzed in this study such as Hypertension, Diabetes, HIV/AIDS and Undiagnosed Illnesses did not reveal a significant risk for HAV contraction within the metropolis respectively $(P \leq 0.68, P \leq 0.76, P \leq 0.86, P \leq 0.66)$.

Education type and level is important in management and control of diseases among humans because it defines an individual's social exposure and at times ability to identify potential risks for infectious disease contraction [21]. The absence of statistically significant associations between the various levels of education and anti-HAV IgM positivity $(P \leq 0.66, P \leq 0.30, P \leq 0.66$, $P \leq 0.43, P \leq 0.82$ ) suggest educational level did not contribute significantly to the seropositivity of anti-HAV IgM among the studied subjects. It could also mean that, all persons at all levels of education have the same predisposition to HAV infection when exposed to the virus regardless of any level of formal education. The 1 (1.79\%) positive cases observed among subjects with a primary school level of Education could probably be due to the presence of children and young adolescent within this age group. This could probably be due to the expo- sure of children to contaminated foods/drinks or contact with contaminated objects on playground. Parents with primary school level of education have also been reported to contribute to higher prevalence of HAV infections among children and young adolescence [2].

\section{Conclusions}

The $0.67 \%$ prevalence rate for HAV infections recorded in this study revealed low endemicity for the Virus within the metropolis. This confirms previous reports of the downward trend in the global seroprevalence of HAV infections. Young Ages (11-20 years, $P \leq 0.04$ ) and blood transfusion $(P \leq 0.04)$ still stand out as potential risks for HAV contraction within the metropolis. There are evidence of improvement in sanitation and Health safety of public eateries within the metropolis.

\section{Recommendations}

1. Education of children and young adolescents on personal hygiene and risks for contraction of HAV, other parasites and pathogens associated with hygiene and sanitation.

2. Proper screening of blood for HAV and other blood pathogens before transfusion.

3. Incorporation of common pathogens associated with disease outbreaks into the curriculum of basic health sciences at elementary studies.

4. Health personnel should enlighten the public about HAV infections and the importance of medical attentions which could avert fulminant hepatitis which can be fatal.

\section{References}

1. Hollinger FB, Ticehurst JR (1996) Hepatitis A Virus. In: Fields BN, Knipe DM, Howley PM, Fields Virology. ( $3^{\text {rd }}$ edn), Lippincott-Raven, Philadelphia, 735-782.

2. Afegbua SL, Bugaje MA, Ahmad AA (2013) Seroprevalence of hepatitis a virus infection among schoolchildren and adolescents in Kaduna, Nigeria. Trans R Soc of Trop Med Hyg 107: 627-630.

3. Hyeokjin L, Hyesook J, Heasun Y, Kisang K, Jong HK, et al. (2012) Genetic analysis of hepatitis A virus strains that induced epidemics in korea during 2007-2009. J Clin Microbiol 50: 1252-1257.

4. Prescott, Harley, Klein (2008) Microbiology. ( $7^{\text {th }}$ edn), McGraw-Hill Publishers, 936-940.

5. World Health Organization (WHO) (2016) Hepatitis A.

6. Bialekm SR, Barry V, Bell BP, Valleroy LA, Behel S, et al. (2011) Seroprevalence and correlates of hepatitis A among HIV-negative american men who have sex with men. Sex Health 8: 343-348.

7. Mohammed Elfatih Al, Humodi AS (2014) Serodetection of hepatitis $A$ virus among Food-handlers in khartoum locality, sudan. American Journal of Research Communication 2: 148-158.

8. Jacobsen $\mathrm{KH}$ (2014) Hepatitis A virus in West Africa: Is an epidemiological transition beginning. Niger Med J 55: 279284. 
9. Manijeh K, Batool SM (2017) Hepatitis A virus infection. Int J Infect 4: e38666.

10. Levinson W (2013) Review of medical microbiology. $\left(12^{\text {th }}\right.$ edn), McGraw Hill Companies Inc, 324-326.

11. United State Centre for Disease Control and Prevention (CDC) (2016) Viral Hepatitis.

12. Murray RP, Rosenthal KS, Kabayashi SG, Pfaller MA (2002) Medical Microbiology. ( $4^{\text {th }}$ edn), Elsevier Publishers, 591-605.

13. Tortora GJ, Berdell FR, Case CL (2008) Microbiology an Introduction. ( $9^{\text {th }}$ edn), Pearson Education Inc Publishers, 764-765.

14. Goering RV, Dockrel HM, Zuberman M, Roitt I M, Chiodin PL (2013) Mims Medical Microbiology. ( $5^{\text {th }}$ edn), Elsevier Sounders, 293-300.

15. Sule WF, Kajogbola AT, Adewumi MO (2013) High prevalence of anti-Hepatitis A virus immunoglobulin $G$ antibody among healthcare facility attendees in Osogbo, Nigeria. J Immunoassay Immunochem 34: 75-82.

16. Jacobsen $\mathrm{KH}$ (2009) The global prevalence of hepatitis A virus infection and susceptibility: A systematic review. World Health Organization, Geneva, Switzerland.

17. Jacobsen KH, Koopman JS (2004) Declining hepatitis A seroprevalence: A global review and analysis. Epidemiol Infect 132: 1005-1022.

18. Arya R, Autonisamy B, Kumar S (2012) Sample size estimation in prevalence studies. Indian J Pediatr 79: 1482-1488.

19. Isa IM, Aminu M, Abdullahi SA, Sani MA, Esona MD (2015) Seroprevalence of hepatitis $B$ virus in a tertiary institution in north -western Nigeria. African Journal of Microbiology Research 9: 171-179.

20. Chanu I, Auwalu U, Muhammad Y, Anthony JD, Timothy W (2016) Epidemiological study of HCV and HIV infections in relation to certain demographic factors among the ante-natal population within kaduna metropolis, Nigeria. International Journal of Infectious Diseases and Therapy 1: 13-21.

21. Waje T, Dadah JA, Muhammad Y, Orukotan A, Ladan Z (2016) Prevalence of Hepatitis $C$ infections among the outpatient population of selected hospitals within kaduna city, Nigeria. Public Health International 1: 33-44.

22. Gossner CM, Severi E, Danielsson N, Hutin Y, Coulombier $D(2015)$ Changing hepatitis A epidemiology in the European Union: New challenges and opportunities. Euro Surveill 20.

23. Chi Square Test Calculator. Social Science Statitistics.

24. https://www.cdc.gov/hepatitis/abc/
25. World Health Organization (WHO) (2009) The global prevalence of hepatitis a virus infection and susceptibility: A systematic review.

26. Manjunatha S, Raghu Kumar KG, Jayasimha VL, Vinod Kumar CS, Satish SP, et al. (2016) Prevalence of hepatitis A virus as cause of acute viral hepatitis in central Karnataka, India. Int J Contemp Pediatr 4: 1-3.

27. Dominiquez A, Bruguera M, Plans P, Costa J, Salleras L (2004) Prevalence of hepatitis a antibodies in schoolchildren in Catalonia (Spain) after the introduction of universal hepatitis a immunization. J Med Virol 73: 172-176.

28. Letaief A, Kaabia N, Gaha R, Bousaadia A, Lazrag F, et al. (2005) Age-specific sero-prevalence of hepatitis A among school children in central Tunisia. Am J Trop Med Hyg 73: 40-43.

29. Al Aziz AM, Awad MA (2008) Seroprevalence of Hepatitis A Virus antibodies among a sample of Egyptian children. East Mediterr Health J 14: 1028-1035.

30. Ikobah JM, Okpara HC, Ekanem EE, Udo J (2015) Seroprevalence and predictors of hepatitis a infection in children. Pan Afr Med J 20: 120.

31. Jason BH, Ashraful IK, Regina CL, David JD, Fahima C, et al. (2005) Blood group, immunity and risk of infection with vibrio cholera in an area of endemicity. Infect Immun 73: 7422-7427.

32. Branch DR (2010) Blood groups and susceptibility to virus infection: New developments. Curr Opin Hematol 17: 558-564.

33. Zaccheaus AJ, Baribefe K, Fiekumo B, Felix E (2008) Prevalence of antibodies to hepatitis $C$ virus in apparently healthy port Harcourt blood donors and association with blood groups and other risk indicators. Blood Transfus 6: 150-155.

34. Aljooani AAO, Noor N AH, Mahmood JM (2012) The infection with $\mathrm{HBV}$ and $\mathrm{HCV}$ and their relationship to $\mathrm{ABO}$ blood group among blood donor. J Fac Med Baghdad 54: 52-56.

35. Naeni AE, Rostami M, Naeini SE (2010) Chronic Viral hepatitis and their relation to ABO blood group and rhesus factor. Med Case Stud 1: 5-7.

36. Tessema B, Yismaw G, Afework K, Anteneh A, Andargachew M, et al. (2010) Seroprevalence of HIV, HBV, HCV and syphilis infections among blood donors at gondar university teaching hospital north west Ethiopia: Declining trends over a period of five years. BMC Infectious diseases 10: 111.

37. United States Centre for Disease Control and Prevention (CDC) (2013) Viral Disease. 